\title{
21 Bar Yoshimin Boiler Maintenance with Controlling Residual Phosphate
}

\author{
Agung Subyakto ${ }^{1 *}$, Afan Hamzah $^{1}$, Agus Surono $^{1}$
}

\begin{abstract}
Boiler as the steam generator is usually utilized as a turbine drive and other industrial processes. Boiler needs good treatment and surveillance to keep its best performance. Boiler water (BW) and boiler feed water (BFW) quality control is essential in boiler maintenance since it preserves boiler from crust, corrosion, and carry over, moreover, it also prevents boiler pipe to break. Boiler maintenance in sugar refinery factory is carried out by controlling the quality of BFW, Chemical injection (inner maintenance) and blowdown of boiler water. BFW mineral content ( $\mathrm{SiO}_{2}$, total hardness) is maintained as small as possible using a softener (cation resin) or demineralization unit (cation and anion resin). Chemical injection is performed by the addition of soda in order to control the pH of boiler water. Phosphate addition aims to tie up total hardness level which is caused by concentration process of water boiler and slipped of hard water from BFW. Blowdown process has purpose to reduce crust and corrosion caused by mineral concentrate inside boiler. The experiment was conducted by controlling pH of BFW from 7.5-8.5, maximum total hardness at 3 ppm, maximum $\mathrm{SiO}_{2}$ concentration at $3 \mathrm{ppm}$ and maximum Total Dissolve Solid (TDS) at 100 ppm while $\mathrm{BW}$ was controlled its $\mathrm{pH}$ at 10.5-11, maximum total hardness at $20 \mathrm{ppm}$, maximum $\mathrm{SiO}_{2}$ concentration at 50 ppm, maximum Total Dissolve Solid (TDS) at 2000 ppm, and residual phosphate ion between $4-10$ ppm. The experiment time was adjusted as a milled day or about for 140 days. The result of the experiment showed that the treatment had a good impact on the condition of the boiler drum pipe.
\end{abstract}

Keywords - Yoshimin Boiler; Blowdown; Carry over; Demineralized unit, Softener

\section{INTRODUCTION}

Boiler is equipment for producing steam at a certain temperature and pressure. It is a closed vessel which heat combustion is contacted to water until it became hot water or steam. In the specific pressure and temperature, hot water or steam has an energy value which is used to transfer heat in the form of heat energy in a process. Boiler needs to be carefully managed and preserve due to the characteristic of the process occurred inside it. When water is boiled until it is transformed into steam, the volume expanded until 1600 times, it will generate energy that has the same characteristic as gunpowder which is easy to explode [1].

Boiler system is differentiated as its output steam function in low pressured boiler and high pressured boiler. These type of boiler system usually are utilized to heat chemical liquid, operating machine and generating electricity by changing thermal energy to mechanical energy which turn generator on. Besides that, There is also process that utilized the combined system. That process used the high pressured and temperature steam to generate electricity and the excess steam from the turbine in the low temperature and pressure state is exploited to the other industrial process [2]. Boiler is also distinguished based on its fluid streamed. It is fire tube boiler and water tube boiler. The fluid that stream in fire tube boiler is combustion gas containing thermal energy that soon to be transferred to BW through heating surface. Fire pipe makes it easier to distribute the thermal energy to the boiler water. Water tube boiler had water streamed in the pipe,

\footnotetext{
I Department of Industrial Chemical Engineering, Faculty of Vocational Studies, Institut Teknologi Sepuluh Nopember, Kampus ITS Sukolilo, Surabaya, 60111. E-mail: glu chem@chem-eng.its.ac.id
}

thermal energy is obtained from furnace room outside the pipe [3].

Water boiler system is consist of BFW and BW. BFW is obtained from condensate water resulted from condensation of used steam from evaporator and external treatment. BFW is treated before by addition of softener (kation resin) or demineralizer (cation and anion resin) [4]. Softener has a function to decrease the hardness of water while demineralizer is able to decrease the hardness from silica ion [5]. When BW is transformed into steam, the solid contents composed of hardness ion, silica ion etc are not evaporated. This makes the solid content becoming concentrate and crust, corrosion and carry over problem arise. Controlling solid concentration is necessary to resolve those problems. the method is by addition of chemical substance (internal treatment) in order to remove the solid content. Phosphate ion is utilized to control calcium crust, $\mathrm{SO}_{3}$ and $\mathrm{N}_{2} \mathrm{H}_{4}$ is used to reduce dissolved oxygen on BW. Furthermore, blowdown process is also applied to resolve those problem. The objective of this study is to understand the boiler maintenance using residual phosphate by controlling some parameters such as $\mathrm{pH}$, total hardness, total dissolved solid and $\mathrm{SiO}_{2}$ concentration.

\section{METHODS}

\section{A. Materials}

Yoshimin Boiler from Japan with 100 ton/hr capacity in sugar refinery factory was used in this study. Polyphosphate, sulfide, and caustic soda are in technical grade. 


\section{B. Experimental}

BFW was treated before entering the boiler. $\mathrm{pH}$ of $\mathrm{BFW}$ was controlled from 7.5-8.5, total hardness was set at maximum $3 \mathrm{ppm}, \mathrm{SiO}_{2}$ concentration was at $3 \mathrm{ppm}$ and maximum TDS of BFW was at $100 \mathrm{ppm}$. After entering the boiler, Polyphosphate, sulfide, and caustic were inserted to boiler through top drum. In the beginning $15 \mathrm{~kg}$ of caustic soda, $7.5 \mathrm{~kg}$ of phosphate and $5 \mathrm{~kg}$ of sulfide was entered to the boiler. After that 6,3 , and $2 \mathrm{~kg}$ of Polyphosphate, sulfide, and caustic, respectively were added periodically (per shift) to the boiler. Some parameters in BW and BFW like $\mathrm{pH}$, TDS, total hardness, alkalinity, silica, phosphate and sulfide content were measured two or three times in a month, the blowdown process was calculated in equation 1

$$
B=\frac{E}{N-1}
$$

Where: $\mathrm{E}=$ stream evaporation rate $(\mathrm{ton} / \mathrm{hr})$

$\mathrm{B}=$ Blowdown, (ton $/ \mathrm{hr}$ )

$\mathrm{N}=$ Concentration cycle

The experiment was carried out for 168 days from Juni $1^{\text {st }}$ 2018.

\section{Analytical}

$\mathrm{pH}$ meter was used to measure the $\mathrm{pH}$ of $\mathrm{BFW}$ and $\mathrm{BW}$. TDS meter was used to measure TDS. Alkalinity and other chemical content were measured using test kit from aquamerk.

\section{RESULT AND DISCUSSION}

Raw water as feed on BFW dan BW contains various substances that can caused problem in boiler. One of the problems is scaling. Scaling in boilers mainly due to hardness and silica content. Total hardness in the either BFW or BW is an obstacle that make the boiler run into scaling problem. Softener or demineralizer is often applied to resolve scaling problem.

Figure 1 shows schematic diagram of reduction process of total hardness.

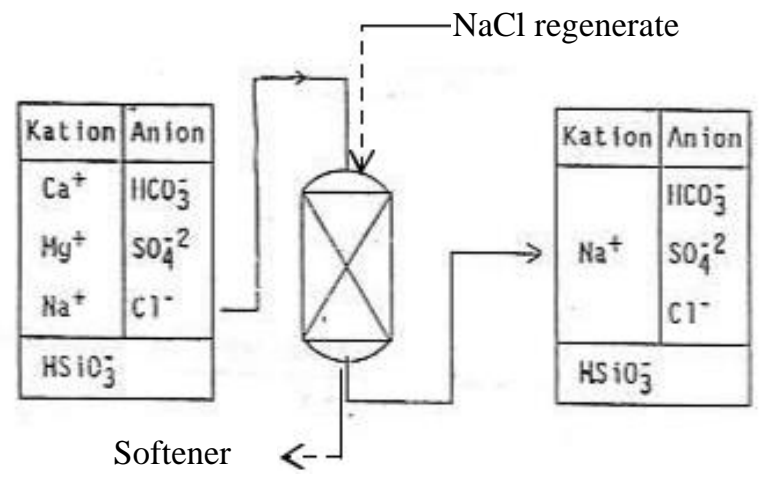

Figure 1. Schematic diagram of reduction of hardness content

The reaction in the decreasing of total hardness occurred as follow:

Hardness absorption

$$
\begin{aligned}
& \mathrm{R}-\left(\mathrm{SO}_{3} \mathrm{Na}\right)_{2}+\mathrm{Ca}^{+2} \\
& \mathrm{R}-\left(\mathrm{SO}_{3} \mathrm{Na}\right)_{2}+\mathrm{Mg}^{+2}
\end{aligned}
$$

$$
\begin{array}{ll}
\text { Regeneration } & \mathrm{R}-\left(\mathrm{SO}_{3} \mathrm{Na}\right)_{2}+\mathrm{CaCl}_{2} \\
\mathrm{R}-\left(\mathrm{SO}_{3}\right)_{2} \mathrm{Ca}+2 \mathrm{NaCl} & \mathrm{R}-\left(\mathrm{SO}_{3} \mathrm{Na}\right)_{2}+\mathrm{MgCl}_{2}
\end{array}
$$

Some parameters were examined correspondence to requirement of $\mathrm{BFW}$ and $\mathrm{BW}$ of Yoshimin Boiler. The requirement is showed at Table 1 .

TABLE 1.

REQUIREMENT PARAMETER OF BFW AND BW

\begin{tabular}{llll}
\hline \hline Parameter & BFW & BW & This study \\
\hline -pH & $7-8$ & $10.5-11.5$ & $10.5-11$ \\
-TDS (ppm) & $<200$ & $<2000$ & $\leq 1800$ \\
-P-alk & & $100-600$ & $100-600$ \\
(ppm) & & $100-800$ & $100-800$ \\
-M-alk & & $<60$ & $\leq 30$ \\
(ppm) & & $20-40$ & $4-8$ \\
-Silica \\
$\begin{array}{l}\text { (ppm) } \\
\text {-Phosphat } \\
\text { (ppm) }\end{array}$ & $<10$ & $10-20$ & $3-6$ \\
-Sulfide \\
$\begin{array}{l}\text { (ppm) } \\
\text {-Total } \\
\text { hardness } \\
\text { (ppm) }\end{array}$ & $<2$ & $<20$ & $\leq 10$ \\
\hline \hline
\end{tabular}

The chemicals were used to control its $\mathrm{pH}$ at 10.5-11, maximum total hardness at $20 \mathrm{ppm}$, maximum $\mathrm{SiO}_{2}$ concentration at $50 \mathrm{ppm}$, TDS at $2000 \mathrm{ppm}$, and residual phosphate ion between $4-10 \mathrm{ppm}$.

\section{A. Boiler Feed Water}

BFW was obtained from two main sources. The first one is condensate water; it was originated from condensation of used steam from evaporator and external process. The second source is from make-up water. Two of them are necessary to be externally treated using softener and/or demineralizer. Softener (cation resin) or demineralizer (cation and anion resin) are able to decrease water hardness and silicate ion content.

$\mathrm{pH}$ of BFW was observed during boiler operation. Figure 1 shows profile of $\mathrm{pH}$ for 168 days. It was revealed that $\mathrm{pH}$ of $\mathrm{BFW}$ maintained at 8 to 9 with maximum $\mathrm{pH}$ was observed at day 126. Figure 3 shows some parameters observed such as TDS, total hardness, Alkalinity $\mathrm{P}$ and $\mathrm{M}$ and Silicate content of BFW. TDS was kept at 42-153 ppm, total Hardness was at 20-90 ppm, P-Alkalinity was at 70210, M-Alkalinity was drastically decreased at 0-3 ppm after the first day, and silica content was kept at about 1-3 ppm. Polyphosphate, sulfide, and caustic were successfully maintained. most of boiler feed water at requirement parameter written in table 1 . However, total hardness had not fulfilled the required parameter yet. It was left as it is because the $\mathrm{BFW}$ would receive the next treatment when it was entered boiler. 


\section{B. Boiler Water}

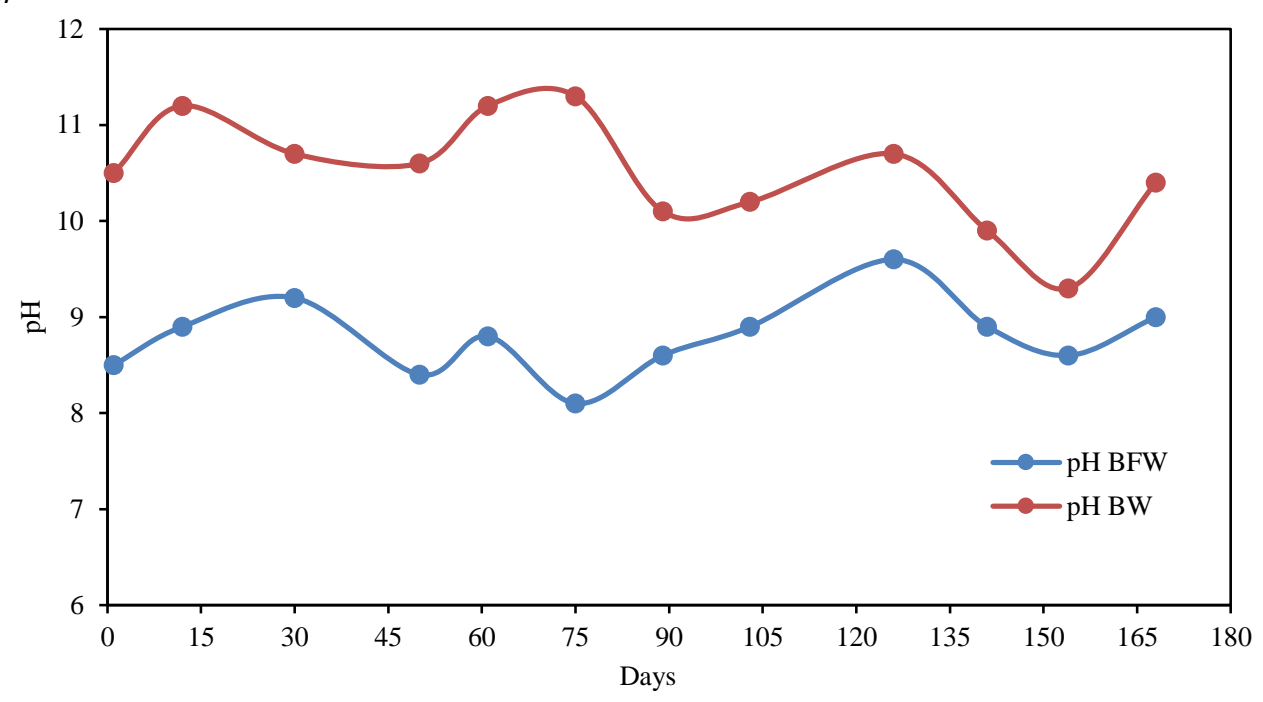

Figure 2. $\mathrm{pH}$ profile of Boiler Feed Water and Boiler Water

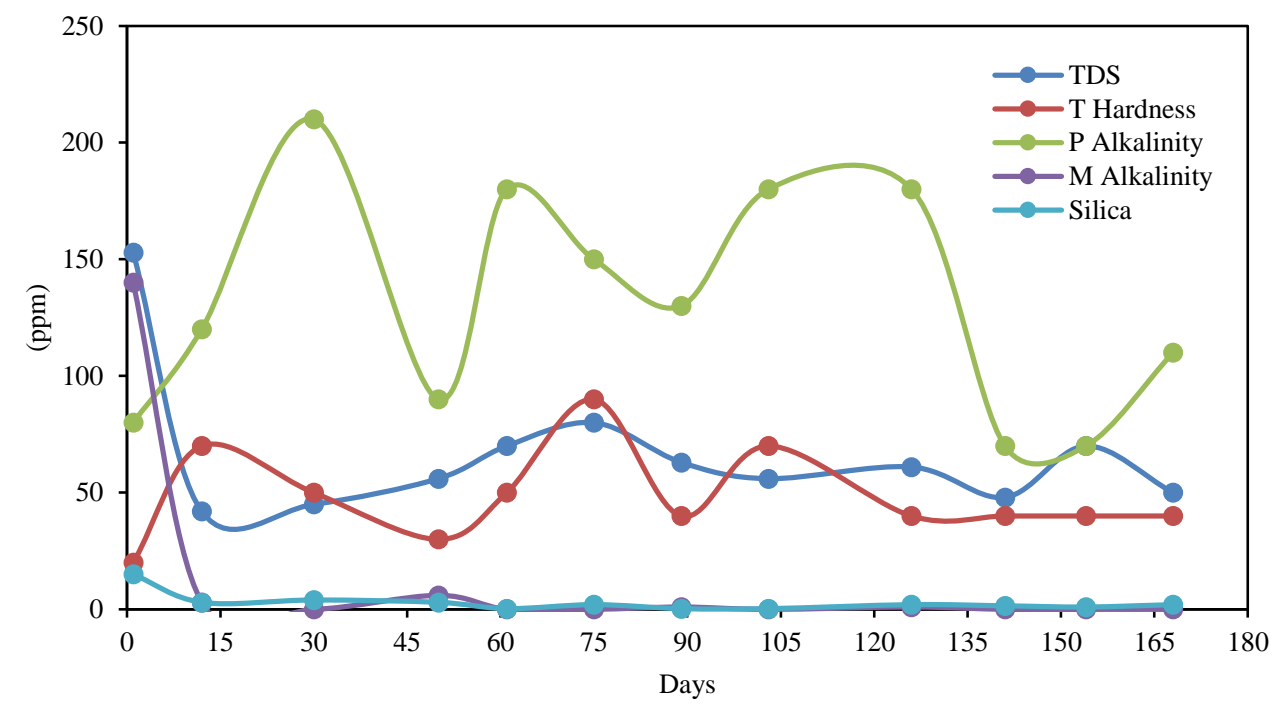

Figure 3. Some parameter observed on Boiler Feed Water

Boiler is an equipment that has function to convert water to steam. When water is evaporated, the solid contents such as hardness ion, silica ion, and other solid is left or do not evaporate. The left behind solid will generate problem like scaling, corrosion and carry over arise.

Some treatments need to be done to prevent those problem occurred. The aim of the treatments is mainly to control solid concentration in water before entering boiler and when water is inside the boiler [6].

Internal treatment or addition of chemical was carried out in this study. The purpose of internal treatment as follow.

- Preventing scaling by calcium by addition of phosphate ion based on this following reaction:

$10 \mathrm{Ca}^{+2}+6 \mathrm{PO}_{4}^{-3}+2 \mathrm{OH}^{-} \longrightarrow\left(\mathrm{Ca}_{3}\left(\mathrm{PO}_{4}\right)_{2}\right)_{3} \mathrm{Ca}(\mathrm{OH})_{2}$ $+10 \mathrm{Na}_{2} \mathrm{CO}_{3}+10 \mathrm{CO}_{2}+10 \mathrm{H}_{2} \mathrm{O}$

- Preventing corrosion from dissolved oxygen by deaerator equipment and supplement of sulfide and hydrazine chemicals.
- Avoiding carry over by decreasing TDS and $\mathrm{pH}$ [5]

In this study, the effects of addition phosphate ion and sulfide ion was mainly studied although controlling blowdown was also performed.

Figure 2 shows $\mathrm{pH}$ of Boiler water during operation. $\mathrm{Ph}$ was kept at 9-10. The requirement that set in this study had already met. Figure 4 shows parameters of BW, that is TDS, Total Hardness and P Alkalinity. TDS reached its highest point at $1166 \mathrm{ppm}$ after 60 days. Total hardness was maintained at about $100-200$ ppm range. P-alkalinity was kept at 200-600 ppm. The other boiler water parameters such as $\mathrm{M}$ alkalinity, silica content, phosphate content and sulfide content are shown in figure 5. M alkalinity was decreased drastically to $0 \mathrm{ppm}$ after 60 days. Silica concentration was preserved under $10 \mathrm{ppm}$ during operation. Phosphate content was maintained at about $10 \mathrm{ppm}$ despite reaching its highest point at $25 \mathrm{ppm}$ on day 60 . Sulfide concentration was kept mostly at under $10 \mathrm{ppm}$ during operation. 
All parameters observed had already fulfilled the requirement set for this study. Supplement of polyphosphate, sulfide, and caustic had effectively preserved the quality of $\mathrm{BFW}$ and BW. inspection was performed at the end of boiler operation (day 168). Figure 6 shows the boiler state after the operation and external and internal treatment were executed. Figure 6 revealed that scaling was still formed. But the thickness of

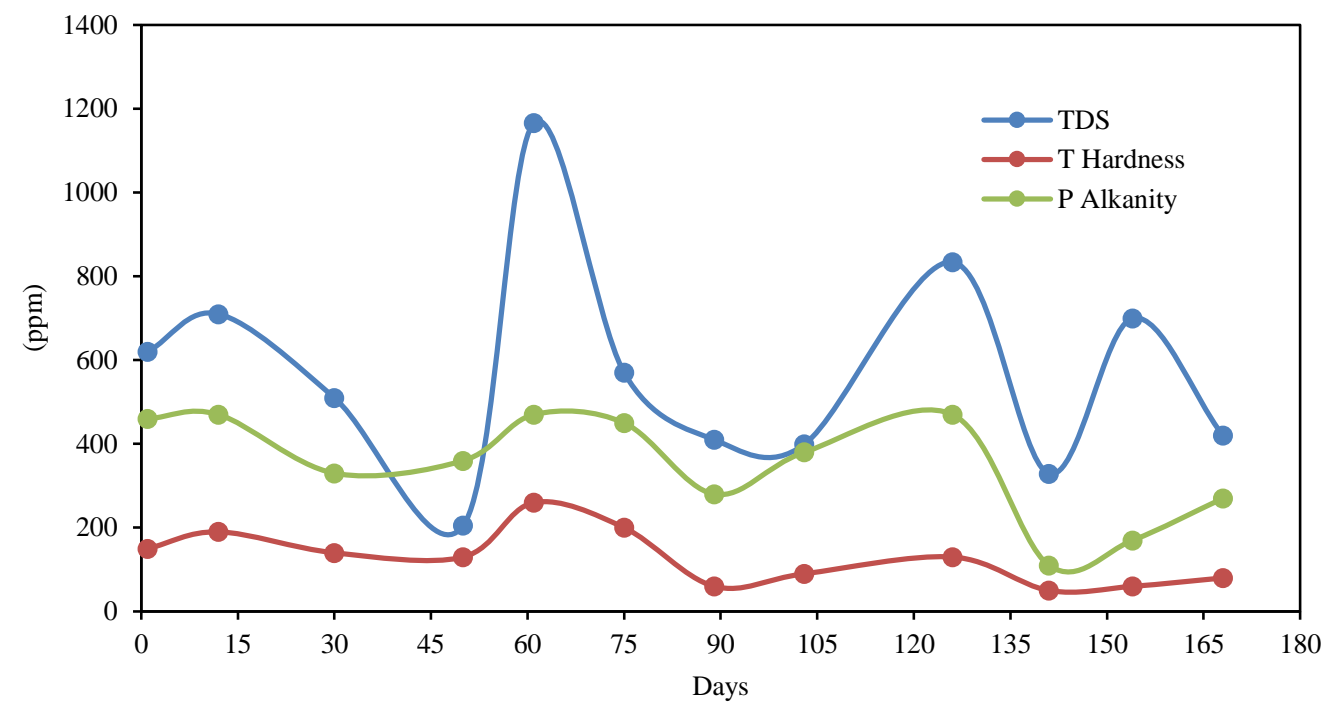

Figure 4. Parameter TDS, Total Hardness, and P Alkanity of Boiler Water

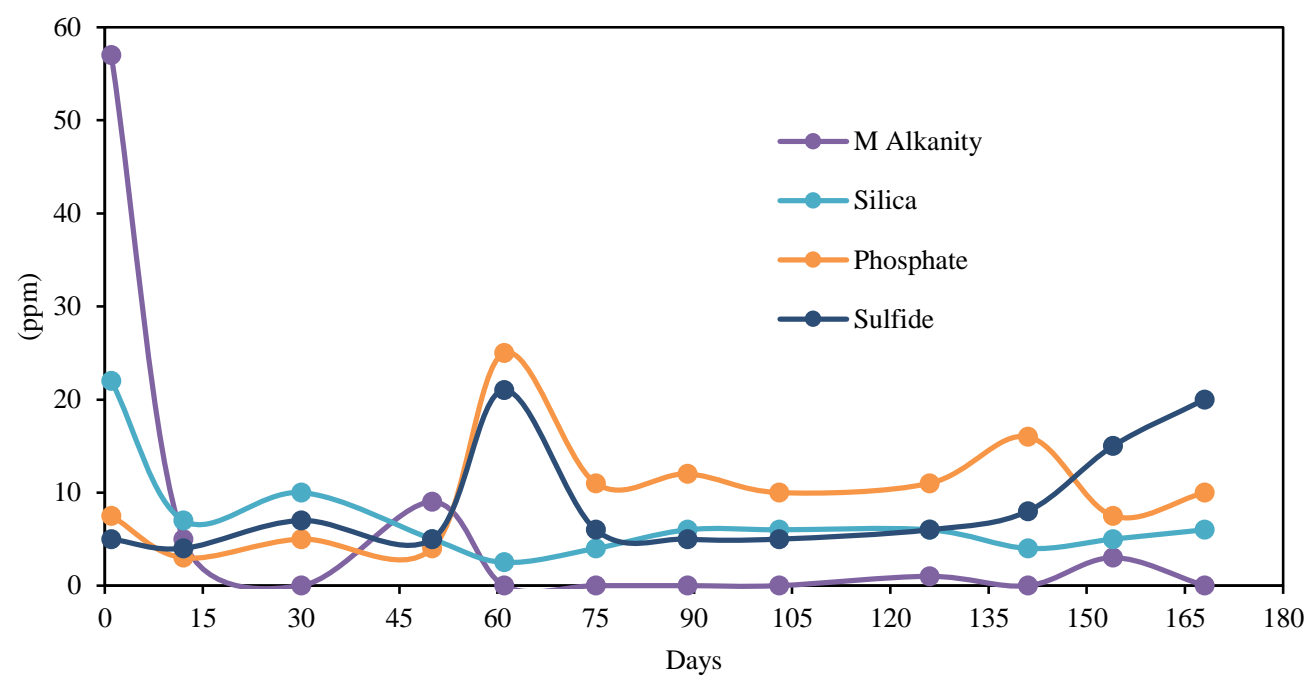

Figure 5. Parameter of Boiler Water
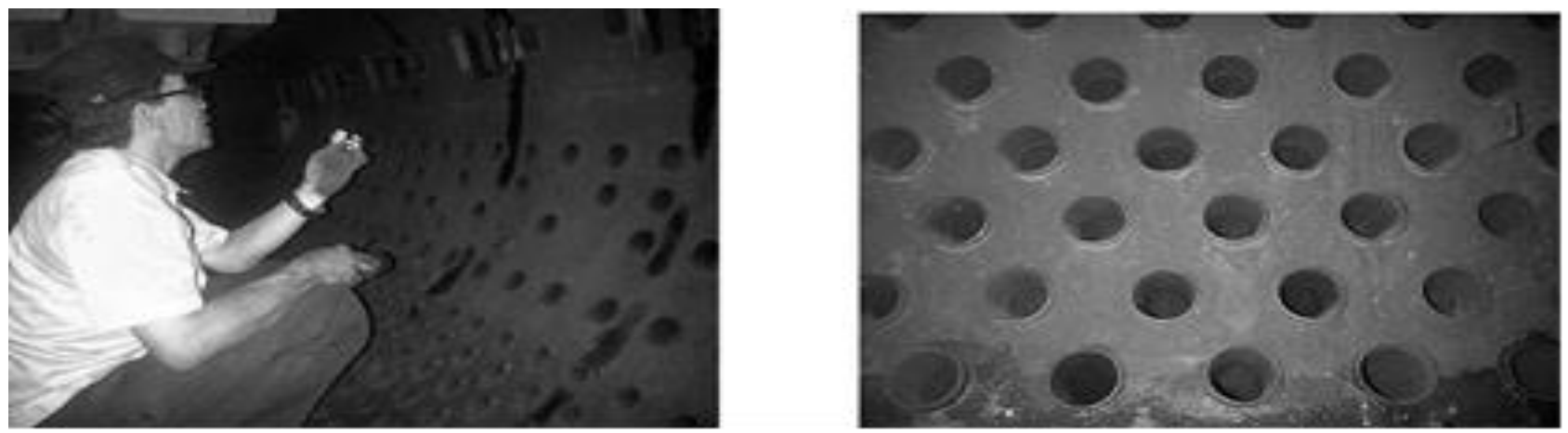

Figure 6. Visual inspection of boiler

\section{Visual Inspection}

After analyzing and observing some parameters mentioned above, visual inspection was also performed. The visual scaling was very thin, there is no indication of corrosion and carry over. So that the boiler did not need chemical cleaning, only mechanical cleaning [7]. 


\section{CONCLUSION}

BFW and BW had been controlled by external and internal treatment using polyphosphate, sulfide, and caustic addition. Some parameters such as TDS, total hardness, $\mathrm{pH}$, alkalinity, silica, phosphate, and sulfide concentration had been met standard. Scaling formed in the end of operation was very thin. The methods of the treatment had been proved effectively prevent scaling, corrosion and carry over.

\section{REFERENCES}

[1] A. Mariajayaprakash and T. Senthilvelan, "Failure detection and optimization of sugar mill boiler using FMEA and Taguchi method," Eng. Fail. Anal., vol. 30, pp. 17-26, 2013, doi: 10.1016/j.engfailanal.2012.12.010.

[2] E. M. Goldratt and E. M. Goldratt, "Chapter 21," Crit. Chain, pp. 203-207, 2018, doi: 10.4324/9781351218986-21.

[3] W. Beyne, S. Lecompte, B. Ameel, D. Daenens, M. Van Belleghem, and M. De Paepe, "Dynamic and steady state performance model of fire tube boilers with different turn boxes," Appl. Therm. Eng., vol. 149, no. September 2018, pp. 1454-1462, 2019, doi: 10.1016/j.applthermaleng.2018.09.103.

[4] E. E. Molinet, Water in Cane Sugar Mills, Its Uses, Care and Treatment for Boiler Feed. Elsevier B.V., 2013.

[5] B. Dong, Y. Xu, S. Jiang, and X. Dai, "Effect of reusing the advanced-softened, silica-rich, oilfieldproduced water (ASOW) on finned tubes in steaminjection boiler," Desalination, vol. 372, pp. 17-25, 2015, doi: 10.1016/j.desal.2015.06.015.

[6] K. K. K. Kurita, Kurita Handbook of Water Treatment second english ed. Tokyo: Kurita Water Industries, 1985.

[7] C. A. Duarte, E. Espejo, and J. C. Martinez, "Failure analysis of the wall tubes of a water-tube boiler," Eng. Fail. Anal., vol. 79, no. January, pp. 704-713, 2017, doi: 10.1016/j.engfailanal.2017.05.032. 